\title{
Waterpipe Smoking and Regulation in the United States: A Comprehensive Review of the Literature
}

\author{
Linda Haddad ${ }^{1, *}$, Omar El-Shahawy ${ }^{2}$, Roula Ghadban ${ }^{3}$, Tracey E. Barnett ${ }^{4}$ and \\ Emily Johnson 5
}

1 College of Nursing, University of Florida, Gainesville, FL 32610, USA

2 Social and Behavioral Health Department, Virginia Commonwealth University, 830 East Main Street, Richmond, VA 23298, USA; E-Mail: elshahwyo@vcu.edu

3 School of Nursing, Virginia Commonwealth University, 821 West Franklin Street, Richmond, VA 23284, USA; E-Mail: ghadbanr@vcu.edu

4 College of Public Health and Health Professions, University of Florida, Gainesville, FL 32610, USA; E-Mail: tebarnett@phhp.ufl.edu

5 College of Health and Human Performance, University of Florida, Gainesville, FL 32610, USA; E-Mail: ejohnson719@hhp.ufl.edu

* Author to whom correspondence should be addressed; E-Mail: 1haddad@ufl.edu; Tel.: +1-352-273-6520.

Academic Editors: Coral Gartner and Britta Wigginton

Received: 2 April 2015 / Accepted: 25 May 2015 / Published: 29 May 2015

\begin{abstract}
Background: Researchers in tobacco control are concerned about the increasing prevalence of waterpipe smoking in the United States, which may pose similar risks as cigarette smoking. This review explores the prevalence of waterpipe smoking in the United States as well as the shortcomings of current U.S. policy for waterpipe control and regulation. Methods: Researchers conducted a literature review for waterpipe articles dated between 2004 and 2015 using five online databases: MEDLINE, CINHAHL, ScienceDirect, PMC, and Cochrane Library. Results: To date, few studies have explored the marketing and regulation of waterpipe smoking in the U.S., which has increased in the last ten years, especially among women, adolescents, and young adults. Data indicate that the majority of waterpipe smokers are unaware of the potential risks of use. In addition, current tobacco control policies do not address waterpipe smoking, enabling tobacco companies to readily market and sell waterpipe products to young adults, who are at risk for becoming lifelong smokers. Conclusion: Policy
\end{abstract}


makers in the area of public health need to update existing tobacco regulations to include waterpipe smoking. Similarly, public health researchers should develop public health campaigns and interventions to address the increasing rates of waterpipe smoking in the United States.

Keywords: waterpipe; hookah; regulation; policy

\section{Introduction}

The smoke inhaled through water pipes use (WPU) contains toxicants similar to cigarettes such as hydrocarbons, carbon monoxide, and carcinogenic polycyclic aromatic volatile aldehydes [1-3]. Despite the fact that the average frequency of WPU in the United States is lower than that of cigarettes, a single WPU session typically lasts for 45 minutes and may produce 50 to 100 times the smoke volume inhaled from a single cigarette [4-8]. Indeed, one study found that once-a-day WP smokers had levels of plasma nicotine concentration comparable to smokers who used 10 cigarettes per day [5,9]. More recent evidence indicates that WPU may have the same health risks as cigarette smoking, such as nicotine addiction, exposure to second hand smoke, and an increased risk for a variety of chronic diseases [10]. Therefore, tobacco control researchers are concerned that WPU has reached a staggering high prevalence rate among young adults $[1,11,12]$. This prevalence may be even higher among college students and young women [13,14] who perceive WPU as more socially acceptable than cigarette smoking [15-17]. Additionally, WPU could provide a gateway to other forms of smoking, which may undermine the advances in tobacco reduction over the last 30 years [18]. In order to potentially reverse this trend, policy makers need reliable scientific information to develop regulations for the marketing, packaging, and consumption of WP in the United States. Thus, this review aims to examine evidence-based research about WPU to inform policy makers and the Food and Drug Administration (FDA) about the needed WPU regulatory actions in the United States.

\section{Methods}

We conducted our literature review between November 2014 and March 2015 via searching for articles published in English between 2005 and 2015, and used the following electronic databases: MEDLINE, CINHAHL, ScienceDirect, PMC, and Cochrane Library. Our search terms were "waterpipe" and its alternative spellings, which were "hookah", "shisha", "narghile", "hubble bubble", and "goza". We limited our search to published research studies; however, gray literature, including published abstracts, conference proceeding, theses, dissertations, and government and organization reports, were also identified.

\section{Study Design}

Our search sample was limited to studies conducted in the United States to address the main outcome of our review, and we included all possible study designs except for review articles. 


\section{Results}

Our searches identified 150 potential relevant papers, of which 100 met inclusion criteria (see Figure 1). Results were comprised of longitudinal and prospective (four), observational/descriptive (crosssectional, survey) (36), reviews of literature/policies (10), measurement scale (one), and social media studies (seven).

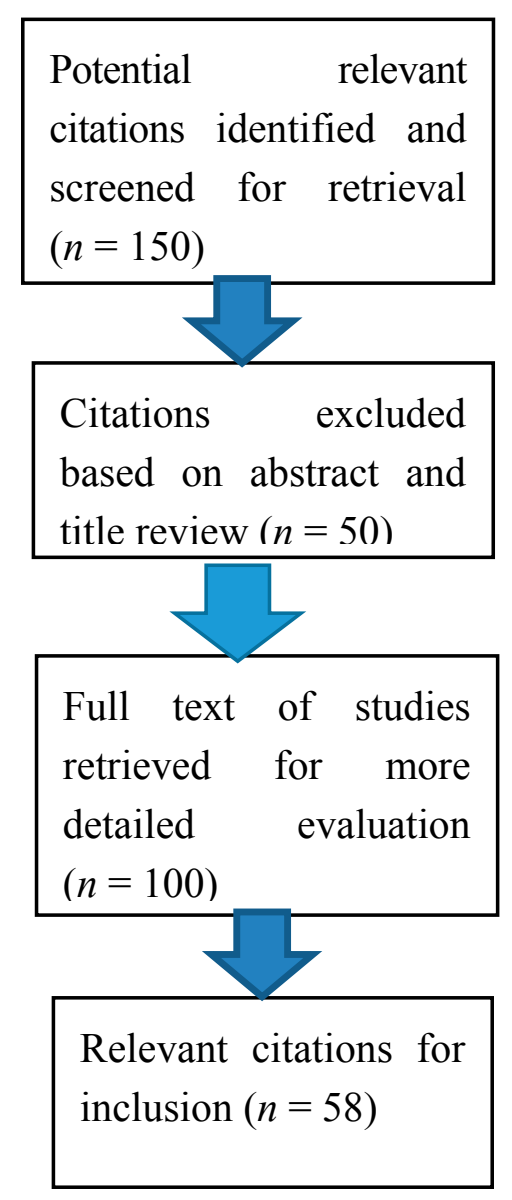

Figure 1. Results of the literature search.

\subsection{Waterpipe Smoking Trends in the U.S.}

Among U.S. high school students, the Center for Disease Control (CDC) reported that cigarette use has dropped by $33 \%$, while use of non-cigarette combustible tobacco products, including WPU, has increased by $123 \%$ (2012). Many studies on the prevalence of WPU in the U.S. focused on high school and college students and results from the 2010 Monitoring the Future study reported that among high school seniors, about one in five (17\%) males and one in six (15\%) females had used waterpipe in the past year [13,14,19-26]. Data indicates that the prevalence of WPU among high school students increased from 11\% in 2007 to over 18\% [13]. Furthermore, Amrock et al., surveyed over 18,000 US adolescents, representing more than 27 million adolescents nationwide, and found that roughly two million adolescents report having ever used waterpipe and 720,000 reported current use [27]. Their results also showed that males were more likely than females to report ever-using waterpipe ( $8.1 \%$ vs. $6.6 \%$, respectively), but were not more likely to report using waterpipe in the past 30 days 
(3.0\% vs. 2.3\%), respectively [27]. However, rates of past use among high school students vary by race, with Whites the most likely (8.4\%) and Blacks the least likely (2.3\%) to smoke WP [27]. Students of other or multiple races $(3.9 \%)$ and Hispanics $(3.3 \%)$ were most likely to report using waterpipe in the past 30 days [27].

One study reported that among all age groups, young adults aged 18-24 have the highest prevalence of WPU (28.6\%) in the United States [28]. Moreover, using the National Adult Tobacco Survey, this study also reported that when compared to people aged between 35 and 44 years, young adults in this age group were eight times more likely to have used waterpipe and were 18 times more likely to report being current users [28]. Among all age groups, overall prevalence rates were lowest among non-Hispanic Blacks (3.6\%) and highest among non-Hispanic Others or those of mixed races (17.6\%) [28]. Furthermore, Salloum et al., reported that those with some college education (but with no degree) and those with annual household incomes over $\$ 100,000$ had the highest rate of past use (12.4\% and $12.0 \%$, respectively [28].

Additionally, Arab American teens reported high WPU (12\%-15\%) [26,29,30] whereas prevalence of WPU among university students ranged widely from $10 \%$ to $46 \%$ [14,21,31-33]. Researchers in the area of tobacco control expect that WPU is likely to increase in young adults because college students view WPU as a socially acceptable group activity. Finally, only one study has examined trends of WPU in U.S. college students with a longitudinal design [22].

Overall, studies in the U.S. indicated that WPU is associated with being male, having peers who smoke waterpipe, and social acceptability $[15,34]$. Other studies in the U.S., which examined the initiation and pattern of WPU at a single time point [15,23,35-37], revealed that WPU had higher social approval than cigarette use had. The gap between males and females is smaller for WPU compared to cigarette smoking. Data indicates that some women prefer WPU to cigarettes, perhaps due to the social environment appeal of WPU or the influence of social media such as Pinterest, which portray WPU in a positive light [38,39]; this could fuel a gender disparity in WPU among women in the US in the near future.

\subsection{Misperceptions of Harm}

Favorable attitudes toward WPU are possibly related to its reported sweet smell and pleasant taste by users; as a result, users view it as an appealing way to spend leisure time socializing with friends [35]. One study utilized the Theory of Reasoned Action to evaluate users' beliefs regarding WPU, results indicated that favorable intentions toward WPU were a significant predictor of use three months later. These intentions explained $50 \%$ of the variance in WPU for study participants, which signifies the importance of those favorable attitudes and "potentially normalized" social norms surrounding waterpipe in the initiation of WPU $[15,35]$.

In addition, many Americans are misinformed about the health risks of WPU [21,35,40,41]. WPU is widely perceived to be less harmful and less addictive than cigarette smoking [15,23,35-37] due to the erroneous belief that water filters the carcinogens in tobacco smoke [42,43]. In fact, waterpipe smoke contains similar toxins to those found in cigarette smoke, including carbon monoxide, and tar; 82 other toxins have been identified. Thus, WPU may pose similar health risks as cigarette smoking, such as cancer, heart disease, and nicotine addiction, which can affect non-smokers through exposure to 
secondhand smoke [43-52]. Two hours of second hand smoke (SHS) exposure in a waterpipe café is considered equivalent to smoking 10 cigarettes per day [39] and exposes users to higher levels of carbon monoxide due to the use of charcoal [53]. Other studies have shown associations between WPU and coronary artery disease [54], lung cancer, low birth weight, and periodontal disease, as well as milder associations between bladder, esophageal cancer, and infertility [55]. Unlike cigarettes, WPU has also been linked to many communicable infectious diseases, including herpes simplex virus and respiratory viruses, which could spread when waterpipe users share hoses.

In response to these misperceptions about health risks, tobacco control researchers examined the perceived health risks of WPU, particularly among young adults [20,35,38,41]. Results of each study were similar: participants perceived WPU to be less harmful than cigarette smoking. This may be because state regulatory agencies have yet to ban waterpipe cafes, which contribute to the misperception that WPU is not as harmful as cigarette smoking. This message may be reinforced further when businesses prominently display, as they are required to do, their favorable health inspection score from their local health department $[4,56]$.

\subsection{Limited Research}

To date, few studies have addressed WPU in relation to its SHS exposure and even fewer have included samples from the United States [2,39,57,58]. Similarly, few published studies have examined the impact of WPU on WP dependence [59]. The majority of the previous studies of WPU in the U.S. have been cross-sectional and all of them were limited to students (high school or college). However, one prospective study followed freshmen women on a monthly basis at a private U.S. college for nine consecutive months during their first academic year of college [22]. This study examined risk and protective factors associated with initiation of WPU and reported that among the participants who reported no pre-college WPU, 23\% initiated use during their first year. Results also showed that alcohol use was associated with the initiation of WPU and marijuana predicted the frequency of use. To date, most cited waterpipe studies were conducted in the Middle East [7-9,11,41,57,60-64] where WPU has strong cultural roots and may be used in different frequencies and patterns than in the U.S.

\subsection{Waterpipe Smoking Appeal}

WPU has a strong social appeal that is making it more popular among users in different countries, including the U.S. For example, in many countries and in parts of the U.S., cigarette smoking among women is considered unacceptable behavior; however, WPU by women does not carry a similar stigma. International studies have validated this double-standard between cigarette and WPU by women $[65,66]$. Perhaps due to the lack of stigma, women in several studies reported that WPU has more positive attributes (e.g., social, attractive, traditional, and familiar) than cigarette smoking and thus prefer this form of tobacco use. Considering the results of these studies, it is not surprising that unlike cigarette smoking/addiction, there is no male gender predominance in WPU [67-69]. 


\subsection{Waterpipe Popularity}

Waterpipe cafés are gaining in popularity in the U.S. and internationally [70] for several reasons. First, waterpipe cafés or bars, unlike traditional bars, do not have strict admissions policies on individuals under age 21 because alcohol is not typically served on the premises [56]. This feature attracts many young adults who seek a social activity with friends but are not old enough to enter a traditional bar. Second, WP cafés provide the same social atmosphere as a bar: the communal waterpipe is the conduit for social interaction. In addition, WPU is generally viewed as "cool", [12,71,72] resulting in peer pressure that may increase the number of individuals who try WPU or who willingly expose themselves to the secondhand smoke in a café setting. In fact, one British study found that WPU increased with time spent in college, whereas the highest level of smoking cigarettes occurred during the first year of school and then decreased. The same study also found that $83.9 \%$ of college students were introduced to WPU by a friend, which is likely to occur more often in the U.S. as the number of waterpipe cafés increases.

\subsection{Waterpipe Social Context}

WPU in a café has typical appeal or social context, which is defined as the immediate, situational, temporal, and motivational factors that influence behavior, is a key influence in the WPU experience [73]. However, at present, little is known about the social context that influences WPU or waterpipe SHS exposurein the U.S. An understanding of the social context of these settings could help explain when, where, why, and with whom young adults prefer to socialize where WPU is known to occur. It is likely that young adults prefer waterpipe cafes because of the informal, social atmosphere, and that WPU may provide an inexpensive way to spend leisure time with friends.

\subsection{Online Media Sources of Waterpipe Information}

Popular online media platforms, such as Twitter and Facebook, play an increasing role in the communication of public health information [6,74]. A recent study [75] found that Americans often rely on online contacts for health information and assign high credibility to their peers' assessments and information. Results also indicated that one third (34\%) of internet users had read commentaries about health issues in news groups, websites, or blogs. Similarly, one fourth $(24 \%)$ had read reviews on drugs and treatments and nearly one-fifth (18\%) had gone online to find people with similar health concerns in order to seek advice and information [75]. This new pattern of information-seeking is important because public health resources, both accurate and inaccurate, can profoundly influence public understanding, attitudes, and behavior [76].

Indeed, in the virtual world, some sources may appear falsely credible [77] and reliable sources may compete with commercial messages to preclude the delivery of accurate information. Myslin et al., examined the content analysis of tobacco-related posts on the popular social media site Twitter to determine sentiment (positive or negative) towards tobacco, including WPU [78]. Researchers analyzed 7362 tobacco-related Twitter posts (i.e., 'tweets') and noted that keywords such as hookah and shisha were classified as showing positive sentiment, compared to the negative sentiment associated with keywords such as nicotine and tobacco. Analogous to other research, these results show that WPU is viewed more favorably than using traditional tobacco products. The researchers also noted that the tweets 
were not posted by recognized health organizations, indicating that much information on Twitter hails from unverified sources.

In a similar study, Salloum et al. [79], utilized data obtained from Google Trends (a publically-accessible database that tracks internet search terms) to assess the popularity of waterpipe internet search queries in four English-speaking countries, including the United States. They report that the online popularity of waterpipe searches was highest in the U.S. compared to the other three countries, and that in the U.S. alone, waterpipe shopping searches (searches conducted under the Google Shopping Category) increased by $291 \%$ between January 2004 and December 2013. They also report that the most common WPU search terms included hookah (approximately 190,000 weekly searches) and shisha (approximately 127,000 weekly searches). The researchers conclude that web-based search queries for waterpipe have steadily increased over the past decade, pointing towards a growing interest in WPU. Thus, researchers in the area of tobacco control must now consider social media in addition to traditional media (e.g., TV, newspaper, web) and offline interpersonal communications to fully understand the conveyance of WP information [77,80-83]. Ultimately, this understanding will enable researchers to develop public health campaigns about the dangers of WPU, resulting in reduced rates of WPU in the U.S. over time.

\subsection{Waterpipe Marketing}

Despite the growth in popularity of WPU, there is minimal literature about the marketing strategies used to promote waterpipe, or "hookah", establishments. For example, some venues offer a variety of Mediterranean and American food and even alcohol, whereas others may attract customers through belly dancers, poker nights, musical performances, or free Wi-Fi access. One study found that advertisements for waterpipe cafes on the Internet used text, images, or audio stimuli to promote waterpipe smoking [56]. Notably, these websites advertised that waterpipe smoking was a safe, fun, relaxing, and "tasty" (i.e., sweet) way to socialize with friends [56]. None of the cafes or websites required age verification, which may entice minors to waterpipe cafes to consume waterpipe products. In addition, many waterpipe companies target youth by offering multiple flavors in their product lineup, which encourages WPU in this population.

\subsection{Industry Regulation}

Because of increasing WPU among young American adults and poor regulation of the waterpipe industry, researchers are concerned that WPU may lead to the use of other tobacco products over time [80,84-86]. Indeed, the growth in WPU indicates a need for waterpipe -specific regulatory policies in the U.S. as well as a need to update existing tobacco laws to include WPU $[18,87]$.

Policy makers in the area of public health should consider the unique aspects of WPU when developing industry regulations. For example, because waterpipe smokers in a café setting do not interact with the packaging, they often do not see the conspicuous warning labels on waterpipe products. Thus, in order to be effective, health-warning labels for waterpipe products would need to be acknowledged by the consumer at point-of-sale, or upon entering the waterpipe café. Also, these cafes, which are considered 'tobacco retail shops' in the U.S., are exempt from the smoke-free laws common in large cities [87]. This exemption is problematic for two reasons: first, it may lead to a high level of waterpipe 
SHS exposureamong the non-smoking customers who attend the cafés [8,41,88-90], and second, it may send a message to the public that waterpipe cafes are "safe" and "normal" [91]. To address this loophole, governments should consider adopting smoke-free laws that broadly define "smoking" as the direct burning or indirect heating of any tobacco or plant product intended for inhalation [92]. With this definition, virtually all smoking products, including WPs, would be included in a regulatory smoking ban.

Policy makers should also consider the exclusion of WPU from laws that govern tobacco products in the United States. For example, the Food and Drug Administration Family Smoking and Prevention Control Act specifies (Section 907, titled 'Tobacco Product Standards') a ban on flavored cigarettes, but fails to mention waterpipe tobacco [93]. This exclusion is worrisome because flavor and smell are considered primary motives for the initiation of WPU [68], largely because they mask the harsh taste of tobacco and make the product smoother and more enjoyable. Notably, the Food and Drug Administration can extend a flavor ban to any tobacco product without an act of Congress [93], and state and local governments can also pass laws banning the sale of flavored tobacco, which can greatly limit WP tobacco sales [85]. (See Table 1, which shows that most tobacco product laws do not include WPU).

Table 1. Summary of federal tobacco product legislation [93].

\begin{tabular}{|c|c|c|}
\hline Legislation & Year & Description \\
\hline $\begin{array}{c}\text { Federal Cigarette Labeling and } \\
\text { Advertising Act (FCLAA) }\end{array}$ & 1965 & $\begin{array}{l}\text { Required warning labels on cigarette packs-“Caution: Cigarette Smoking } \\
\text { May Be Hazardous to Your Health"; however, this law did not apply to } \\
\text { tobacco-related advertisements }\end{array}$ \\
\hline Public Health Cigarette Smoking Act & 1970 & Banned cigarettes ads on the radio or television \\
\hline $\begin{array}{l}\text { Comprehensive Smoking Education } \\
\text { Act (Public Law 98-474) }\end{array}$ & 1984 & $\begin{array}{l}\text { Required four rotating health warning labels (all listed as Surgeon General's } \\
\text { Warnings) on cigarette packages and advertisements } \\
\text { Required cigarette industry to provide a confidential list of ingredients } \\
\text { added to cigarettes manufactured in or imported into the United States }\end{array}$ \\
\hline Public Law 100-202 & 1987 & Banned smoking on domestic airline flights scheduled for two hours or less \\
\hline Public Law 101-164 & 1989 & Banned smoking on domestic airline flights scheduled for six hours or less \\
\hline Pro-Children Act & 1994 & $\begin{array}{l}\text { Required all federally funded children's services to become smoke-free. } \\
\text { Expanded upon } 1993 \text { law that banned smoking in Women, Infants, and } \\
\text { Children (WIC) clinics }\end{array}$ \\
\hline $\begin{array}{l}\text { Family Smoking Prevention and } \\
\text { Tobacco Control Act (Tobacco } \\
\text { Control Act) }\end{array}$ & 2009 & $\begin{array}{l}\text { Gave FDA authority to regulate the manufacturing, distribution, and } \\
\text { marketing of tobacco products } \\
\text { Required that smokeless tobacco packages and advertisements have larger } \\
\text { and more visible and effective warnings. Smokeless tobacco includes } \\
\text { tobacco products such as moist snuff, chewing tobacco, and snus. } \\
\text { Established and enforced restrictions on tobacco advertising } \\
\text { and promotions } \\
\text { Required tobacco companies to disclose what is in their products } \\
\text { Only included cigarettes, cigarette tobacco, roll-your-own tobacco, and } \\
\text { smokeless tobacco }\end{array}$ \\
\hline
\end{tabular}


Table 1. Cont.

\begin{tabular}{|c|c|c|}
\hline Legislation & Year & Description \\
\hline $\begin{array}{c}\text { Center for Tobacco Products ban on } \\
\text { flavored tobacco }\end{array}$ & 2009 & $\begin{array}{l}\text { Banned the sale or distribution of any cigarettes containing an artificial or } \\
\text { natural flavor other than tobacco. This ban did not apply to menthol. }\end{array}$ \\
\hline $\begin{array}{l}\text { Regulations Restricting the Sale and } \\
\text { Distribution of Cigarettes and } \\
\text { Smokeless Tobacco to Protect } \\
\text { Children and Adolescents (Under the } \\
\text { Tobacco Control Act) }\end{array}$ & 2010 & $\begin{array}{l}\text { Designed to curb access to cigarettes and smokeless tobacco products to } \\
\text { children and adolescents in the United States } \\
\text { Prohibited the sale of cigarettes, cigarette tobacco, and smokeless tobacco } \\
\text { to people younger than } 18 \text {. } \\
\text { Prohibited the sale of cigarette packages with fewer than } 20 \text { cigarettes. } \\
\text { Prohibited the sale of cigarettes and smokeless tobacco in vending } \\
\text { machines, self-service displays, or other impersonal modes of sales, except } \\
\text { in very limited situations. } \\
\text { Prohibited free samples of cigarettes and limit distribution of smokeless } \\
\text { tobacco products }\end{array}$ \\
\hline $\begin{array}{l}\text { Tobacco Products Deemed To Be } \\
\text { Subject to the Food, Drug \& } \\
\text { Cosmetic Act }\end{array}$ & $\begin{array}{l}\text { In } \\
\text { progress }\end{array}$ & $\begin{array}{l}\text { Proposed newly 'deemed' products would include electronic cigarettes, } \\
\text { cigars, pipe tobacco, certain dissolvables that are not smokeless 'tobacco', } \\
\text { gels, and waterpipe tobacco }\end{array}$ \\
\hline
\end{tabular}

Finally, policy makers could consider reducing access to waterpipe products through an increase in taxes and strict legislation. For example, the current price of waterpipw tobacco is approximately $\$ 22$ per pound less than the price of cigarette tobacco [85,94]. If policy makers increased the price of waterpipe tobacco to be equal to that of cigarette tobacco, then waterpipe products would be less affordable, particularly to young adults who are most likely to consume them. Policy makers could also reduce access to waterpipe products by regulating their portrayal on social media (e.g., Twitter and Facebook) $[95,96]$ and retail webpages, as well as limiting access to online vendors, and creating age restrictions for the sale of waterpipe products. All of these regulatory methods show great promise in reducing the rates of WPU over time, particularly among heavy consumers of waterpipe products, such as women and young adults.

\section{Conclusions}

WPU is increasing in popularity due to few regulatory laws and public attraction to this new and "cool" form of smoking. Presently, there is ample international research on WPU, but few studies have been conducted in the U.S. about the marketing and regulation of waterpipe as well as current trends in use, we provide a list of included studies and their design in the appendix (Table A1). Thus, more research is needed that targets vulnerable populations (e.g., young adults and/or women in college towns) to determine their (a) current perceptions of the health risks of WPU; (b) access to and quality of online media information about WPU; and (c) willingness to engage in a public health intervention to reduce WPU. The same successful strategies that have been used for cigarette smoking could be applied to WPU. Our findings show there is much room for development of waterpipe policy and until the FDA extends its regulatory authority to the waterpipe industry, state policy makers need to revise existing cigarette-specific legislation to include WPU. Such changes may profoundly affect rates of WPU over time. 


\section{Acknowledgments}

The authors would like to acknowledge Debra McDonald for her editorial support.

\section{Author Contributions}

Linda Haddad prepared the study design and did the primary validation of all literature search results and wrote the first draft of the manuscript. Omar El-Shahawy wrote the results section of the manuscript, and reviewed and edited the draft of the manuscript. Roula Ghadban validated all the literature results. Tracey Barnett helped analyze results and findings. Emily Johnson collected all potential relevant citations and conducted an initial screening of titles and abstracts.

\section{Appendix}

Table A1. List of included studies and their design.

\begin{tabular}{lc}
\hline \multicolumn{1}{c}{ Authors } & Design \\
\hline Shishani, K.; Howell, D.; McPherson, S.; Roll, J. Young adult waterpipe & \\
smokers: Smoking behaviors and associated subjective and physiological & \\
effects. Addict. Behav. 2014, 39, 1113-1119. & \\
Villanti, A.C.; Cobb, C.O.; Cohen, A.M.; Williams, V.F.; Rath, J.M. & \\
Correlates of hookah use and predictors of hookah trial in U.S. young & Longitudinal and \\
adults. Am. J. Prev. Med. 2015. & Prospective \\
Fielder, R.L.; Carey, K.B.; Carey, M.P. Predictors of initiation of hookah & \\
tobacco smoking: A one-year prospective study of first-year college & \\
women. Psychol. Addict. Behav. 2012, 26, 963-968. & \\
Fielder, R.L.; Carey, K.B.; Carey, M.P. Hookah, cigarette, and marijuana & \\
use: A prospective study of smoking behaviors among first-year college & \\
women. Addict. Behav. 2013, 38, 2729-2735. & \\
\hline
\end{tabular}


Table A1. Cont.

\begin{tabular}{l} 
Authors \\
\hline Rezk-Hanna, M.; Macabasco-O'Connell, A.; Woo, M. Hookah smoking \\
among young adults in Southern California. Nurs. Res. 2014, 63, \\
300-306. \\
Amrock, S.M.; Gordon, T.; Zelikoff, J.T.; Weitzman, M. Hookah use \\
among adolescents in the United States: Results of a national survey. \\
Nicotine Tob. Res. 2014, 16, 231-237. \\
Linde, B.D.; Ebbert, J.O.; Pasker, C.K.; Talcott, G.W.; Schroeder, D.R.; \\
Hanson, A.C.; Klesges, R.C. Prevalence and predictors of hookah use in US \\
air force military recruits. Addict. Behav. 2015, 47, 5-10. \\
Palamar, J.J.; Zhou, S.; Sherman, S.; Weitzman, M. Hookah use among US \\
high school seniors. Pediatrics 2014, 134, 227-234. \\
Goodwin, R.D.; Grinberg, A.; Shapiro, J.; Keith, D.; McNeil, M.P.; \\
Taha, F.; Jiang, B.; Hart, C.L. Hookah use among college students: \\
Prevalence, drug use, and mental health. Drug Alcohol Depen. 2014, 141, \\
16-20. \\
Grifith, M.A.; Ford, E.W. Hookah Smoking: Behaviors and beliefs among \\
young consumers in the United Staes. Soc. Work Pub. Health 2014, 29, \\
17-26. \\
Primack, B.A.; Longacre, M.R.; Beach, M.L.; Adachi-Mejia, A.M.; \\
Titus, L.J.; Dalton, M.A. Association of established smoking among \\
adolescents with timing of exposure to smoking depicted in movies. J. Natl. \\
Cancer Inst. 2012, 104, 549-555. \\
Rice, V.H.; Weglicki, L.S.; Templin, T.; Jamil, H.; Hammad, A. \\
Intervention effects on tobacco use in Arab and non-Arab American \\
adolescents. Addict. Behav. 2010, 35, 46-48. \\
Primack, B.; Sidani, J.; Shadel, W.; Eissenberg, T. Prevalence of and \\
associations with waterpipe tobacco smoking among U.S. University \\
students. Ann. Behav. Med. 2008, 36, 81-86. \\
Sterling, K.L.; Mermelstein, R. Examining hookah smoking among a cohort \\
of adolescent ever smokers. Nicotine Tob. Res. 2011, 13, 1202-1209. \\
\hline
\end{tabular}


Table A1. Cont.

\begin{tabular}{|c|c|}
\hline Authors & Design \\
\hline \multicolumn{2}{|l|}{ Lipkus, I.M.; Eissenberg, T.; Schwartz-Bloom, R.D.; Prokhorov, A.V.; } \\
\hline \\
\hline \multicolumn{2}{|l|}{ waterpipe tobacco smokers. Nicotine Tob. Res. 2011, 13, 599-610. } \\
\hline \\
\hline \multirow{2}{*}{\multicolumn{2}{|c|}{$\begin{array}{l}\text { narghile (waterpipe) use: The first insights on tobacco dependence in } \\
\text { narghile users. Drug Alcohol Depend. 2004, 76, 101-106. }\end{array}$}} \\
\hline & \\
\hline \multicolumn{2}{|l|}{ Sukaina Alzyoud, L.H.; Omar, E.S.; Roula, G.; Khalid, K.; Khalid, A.A.; } \\
\hline \multicolumn{2}{|l|}{ Yan, J. Patterns of waterpipe use among Arab immigrants in the USA: } \\
\hline \multicolumn{2}{|l|}{ A pilot study Br. J. Med. Med. Res. 2014, 4, 11 . } \\
\hline \multicolumn{2}{|l|}{ Primack, B.A.; Shensa, A.; Kim, K.H.; Carroll, M.V.; Hoban, M.T.; } \\
\hline \multirow{2}{*}{\multicolumn{2}{|c|}{$\begin{array}{l}\text { Leino, E.V.; Eissenberg, T.; Dachille, K.H.; Fine, M.J. Waterpipe smoking } \\
\text { among U.S. University students. Nicotine Tob. Res. 2013, 15, 29-35. }\end{array}$}} \\
\hline & \\
\hline \multicolumn{2}{|l|}{ Barnett, T.E.; Forrest, J.R.; Porter, L.; Curbow, B.A. A multiyear } \\
\hline \multicolumn{2}{|l|}{ assessment of hookah use prevalence among Florida high school students. } \\
\hline \multicolumn{2}{|l|}{ Nicotine Tob. Res. 2014, 16, 373-377. } \\
\hline \multicolumn{2}{|l|}{ Barnett, T.; Smith, T.; He, Y.; Soule, E.; Curbow, B.; Tomar, S.; } \\
\hline \multicolumn{2}{|l|}{ McCarty, C. Evidence of emerging hookah use among university students: } \\
\hline \multicolumn{2}{|l|}{ A cross-sectional comparison between hookah and cigarette use. $B M C$} \\
\hline \multicolumn{2}{|l|}{ Public Health 2013, 13, 302.} \\
\hline \multicolumn{2}{|l|}{ Noonan, D.; Patrick, M.E. Factors associated with perceptions of hookah } \\
\hline $\begin{array}{l}\text { addictiveness and harmfulness among young adults. Subst. Abuse 2013, 34, } \\
83-85 \text {. }\end{array}$ & Observational/Descriptive \\
\hline Sidani, J.E.; Shensa, A.; Primack, B.A. Substance and hookah use and & (cross-sectional, survey) \\
\hline \multicolumn{2}{|l|}{ living arrangement among fraternity and sorority members at US colleges } \\
\hline \multicolumn{2}{|l|}{ and universities. J. Commun. Health 2013, 38, 238-245. } \\
\hline \multicolumn{2}{|l|}{ Abughosh, S.; Wu, I.H.; Peters, J.R. Predictors of persistent waterpipe } \\
\hline \multicolumn{2}{|l|}{ smoking among university students in the United States. Epidemiology: } \\
\hline \multicolumn{2}{|l|}{ Open Access 2011, 01 . } \\
\hline \multicolumn{2}{|l|}{ Noonan, D.; Kulbok, P.; Yan, G. Intention to smoke tobacco using a } \\
\hline \multicolumn{2}{|l|}{ waterpipe among students in a southeastern U.S. College. Public Health } \\
\hline \multicolumn{2}{|l|}{ Nurs. 2011, 28, 494-502. } \\
\hline Primack, B.A.; Kim, K.H.; Shensa, A.; Sidani, J.E.; Barnett, T.E.; & \\
\hline Switzer, G.E. Tobacco, marijuana, and alcohol use in university students: & \\
\hline A cluster analysis. J. Am. Coll. Health 2012, 60, 374-386. & \\
\hline Rice, V.H.; Weglicki, L.S.; Templin, T.; Hammad, A.; Jamil, H.; & \\
\hline Kulwicki, A. Predictors of Arab American adolescent tobacco use. & \\
\hline Merrill Palmer $Q$ (Wayne State Univ Press) 2006, 52, 327-342. & \\
\hline Jamil, H.; Templin, T.; Fakhouri, M.; Rice, V.H.; Khouri, R.; Fakhouri, H. & \\
\hline Comparison of personal characteristics, tobacco use, and health states in & \\
\hline Chaldean, Arab American, and non-Middle Eastern white adults. J. Immigr. & \\
\hline Minor. Health 2009, 11, 310-317. & \\
\hline Primack, B.A.; Fertman, C.I.; Rice, K.R.; Adachi-Mejia, A.M.; Fine, M.J. & \\
\hline Waterpipe and cigarette smoking among college athletes in the United & \\
\hline States. J. Adolescent Health 2010, 46, 45-51. & \\
\hline
\end{tabular}


Table A1. Cont.

\begin{tabular}{|c|c|}
\hline Authors & Design \\
\hline \multicolumn{2}{|l|}{ Backinger, C.L.; Fagan, P.; O’Connell, M.E.; Grana, R.; Lawrence, D.; } \\
\hline \multirow{3}{*}{\multicolumn{2}{|c|}{$\begin{array}{l}\text { Bishop, J.A.; Gibson, J.T. Use of other tobacco products among U.S. adult } \\
\text { cigarette smokers: Prevalence, trends and correlates. Addict. Behav. 2008, } \\
\text { 33, 472-489. }\end{array}$}} \\
\hline & \\
\hline & \\
\hline \\
\hline \multirow{2}{*}{\multicolumn{2}{|c|}{ tobacco using a waterpipe among college students. J. Addict. Nurs. $\mathbf{2 0 1 2}$, }} \\
\hline & \\
\hline \multicolumn{2}{|l|}{ Nuzzo, E.; Shensa, A.; Kim, K.H.; Fine, M.J.; Barnett, T.E.; Cook, R.; } \\
\hline \multicolumn{2}{|l|}{ Primack, B.A. Associations between hookah tobacco smoking knowledge } \\
\hline \multicolumn{2}{|l|}{ and hookah smoking behavior among US college students. Health Edu. Res. } \\
\hline \multicolumn{2}{|l|}{$\mathbf{2 0 1 3}, 28,92-100$} \\
\hline \multirow{2}{*}{\multicolumn{2}{|c|}{$\begin{array}{l}\text { Primack, B.A.; Walsh, M.; Bryce, C.; Eissenberg, T. Water-pipe tobacco } \\
\text { smoking among middle and high school students in Arizona. Pediatrics }\end{array}$}} \\
\hline & \\
\hline \multicolumn{2}{|l|}{$\mathbf{2 0 0 9}, 123, \mathrm{e} 282-\mathrm{e} 288$} \\
\hline \multicolumn{2}{|l|}{ Jacob, P., 3rd; Abu Raddaha, A.H.; Dempsey, D.; Havel, C.; Peng, M.; } \\
\hline \multicolumn{2}{|l|}{ Yu, L.; Benowitz, N.L. Nicotine, carbon monoxide, and carcinogen } \\
\hline \multicolumn{2}{|l|}{ exposure after a single use of a water pipe. Cancer Epidemiol. Biomarkers } \\
\hline \multicolumn{2}{|l|}{ Prev. 2011, 20, 2345-2353. } \\
\hline \multicolumn{2}{|l|}{$\begin{array}{l}\text { Shihadeh, A.L.; Eissenberg, T.E. Significance of smoking machine toxicant } \\
\text { yields to blood-level exposure in water pipe tobacco smokers. Cancer }\end{array}$} \\
\hline \multicolumn{2}{|l|}{ Epidemiol. Biomarkers Prev. 2011, 20, 2457-2460. } \\
\hline \multicolumn{2}{|l|}{ Islami, F.; Nasseri-Moghaddam, S.; Pourshams, A.; Poustchi, H.; } \\
\hline \multicolumn{2}{|l|}{ Semnani, S.; Kamangar, F.; Etemadi, A.; Merat, S.; Khoshnia, M.; } \\
\hline \multirow{2}{*}{\multicolumn{2}{|c|}{$\begin{array}{l}\text { Dawsey, S.M., et al. Determinants of gastroesophageal reflux disease, } \\
\text { including hookah smoking and opium use- a cross-sectional analysis of }\end{array}$}} \\
\hline & \\
\hline \multicolumn{2}{|l|}{ 50,000 individuals. PloS One 2014, 9, e89256. } \\
\hline \multicolumn{2}{|l|}{ Barnett, T.E.; Curbow, B.A.; Soule, E.K., Jr.; Tomar, S.L.; Thombs, D.L. } \\
\hline \multicolumn{2}{|l|}{ Carbon monoxide levels among patrons of hookah cafes. Am. J. Prev. Med. } \\
\hline \multicolumn{2}{|l|}{ 2011, 40, 324-328. } \\
\hline \multirow{3}{*}{\multicolumn{2}{|c|}{$\begin{array}{l}\text { Akl, E.A.; Jawad, M.; Lam, W.Y.; Co, C.N.; Obeid, R.; Irani, J. Motives, } \\
\text { beliefs and attitudes towards waterpipe tobacco smoking: A systematic } \\
\text { review. Harm. Reduct. J. 2013, 10, } 12 \text {. }\end{array}$}} \\
\hline & \\
\hline & \\
\hline \multicolumn{2}{|l|}{ Sharma, E.; Beck, K.H.; Clark, P.I. Social context of smoking hookah } \\
\hline \multicolumn{2}{|l|}{ among college students: Scale development and validation. J. Am. College } \\
\hline \multicolumn{2}{|l|}{ Health 2013, 61, 204-211. } \\
\hline \multirow{2}{*}{\multicolumn{2}{|c|}{$\begin{array}{l}\text { Myslin, M.; Zhu, S.H.; Chapman, W.; Conway, M. Using Twitter to } \\
\text { examine smoking behavior and perceptions of emerging tobacco products. }\end{array}$}} \\
\hline & \\
\hline J. Med. Intern. Res. 2013, 15, e174. & \\
\hline Salloum, R.G.; Thrasher, J.F.; Kates, F.R.; Maziak, W. Water pipe tobacco & \\
\hline smoking in the United States: Findings from the National Adult Tobacco & \\
\hline Survey. Prev. Med. 2015, 71, 88-93. & \\
\hline
\end{tabular}


Table A1. Cont.

\begin{tabular}{|c|c|}
\hline Authors & Design \\
\hline $\begin{array}{l}\text { Salloum, R.G.; Thrasher, J.F.; Kates, F.R.; Maziak, W. Waterpipe tobacco } \\
\text { smoking in the United States: Findings from the National Adult Tobacco } \\
\text { Survey. Prev. Med. 2015, 71, 88-93. } \\
\text { Primack, B.A.; Hopkins, M.; Hallett, C.; Carroll, M.V.; Zeller, M.; } \\
\text { Dachille, K.; Kim, K.H.; Fine, M.J.; Donohue, J.M.U.S. Health policy } \\
\text { related to hookah tobacco smoking. Am. J. Public Health 2012, 102, } \\
\text { e47-e51. } \\
\text { Akl, E.A.; Gunukula, S.K.; Aleem, S.; Obeid, R.; Jaoude, P.A.; Honeine, R.; } \\
\text { Irani, J. The prevalence of waterpipe tobacco smoking among the general } \\
\text { and specific populations: A systematic review. BMC Public Health 2011, } \\
\text { 11, 244. } \\
\text { WHO Study Group on Tobacco Product Regulation. Advisory note: } \\
\text { Waterpipe Tobacco Smoking: Health Effects, Research Needs and } \\
\text { Recommended actions by Regulators; World Health Organization: Geneva, } \\
\text { Switzerland, 2005. } \\
\text { Chaouachi, K. Hookah (shisha, narghile) smoking and environmental } \\
\text { tobacco smoke: A critical review of the relevant literature and the public } \\
\text { health consequences. Int. J. Environ. Res. Public Health 2009, 6, 798-843. } \\
\text { Griffiths, M.A.; Harmon, T.R.; Gilly, M.C. Hubble bubble trouble: The need } \\
\text { for education about and regulation of hookah smoking. J Pub. Pol. Mark. } \\
\text { 2011, 30, 119-132. } \\
\text { Morris, D.S.; Fiala, S.C.; Pawlak, R. Opportunities for policy interventions } \\
\text { to reduce youth hookah smoking in the United States. Prev. Chronic Dis. } \\
\text { 2012, 9, E165. } \\
\text { McCarthy, M. FDA moves to regulate e-cigarettes and pipe and hookah } \\
\text { tobacco. BMJ 2014, 348, g2952. } \\
\text { Maher, J.E.; Morris, D.S.; Girard, K.E.; Pizacani, B.A. Consequences of } \\
\text { clean indoor air exemptions in Oregon: The hookah story. Tob. Control } \\
\text { 2014, 23, 195-196. } \\
\text { Jawad, M.; McEwen, A.; McNeill, A.; Shahab, L. To what extent should } \\
\text { waterpipe tobacco smoking become a public health priority? Addiction 2013, } \\
\text { 108, 1873-1884. } \\
\text { Elias, W.; Assy, N.; Elias, I.; Toledo, T.; Yassin, M.; Bowirrat, A. The } \\
\text { detrimental danger of water-pipe (hookah) transcends the hazardous } \\
\text { consequences of general health to the driving behavior. J. Transl. Med. } \\
\text { 2012, 10, 126. }\end{array}$ & $\begin{array}{c}\text { Review of } \\
\text { literature/policies }\end{array}$ \\
\hline $\begin{array}{l}\text { Sharma, E.; Beck, K.H.; Clark, P.I. Social context of smoking hookah } \\
\text { among college students: scale development and validation. J. Am. College } \\
\text { Health 2013, 61, 204-211. }\end{array}$ & Measurement scale \\
\hline $\begin{array}{l}\text { Kassem, N.O.; Daffa, R.M.; Liles, S.; Jackson, S.R.; Kassem, N.O.; } \\
\text { Younis, M.A.; Mehta, S.; Chen, M.; Jacob, P., 3rd; Carmella, S.G.; et al. } \\
\text { Children's exposure to secondhand and thirdhand smoke carcinogens and } \\
\text { toxicants in homes of hookah smokers. Nicotine Tob. Res. 2014, 16, } \\
\text { 961-975. }\end{array}$ & Health effect \\
\hline
\end{tabular}


Table A1. Cont.

\begin{tabular}{l}
\hline \multicolumn{1}{c}{ Authors } \\
\hline Primack, B.A.; Rice, K.R.; Shensa, A.; Carroll, M.V.; DePenna, E.J.; \\
Nakkash, R.; Barnett, T.E. U.S. Hookah tobacco smoking establishments \\
advertised on the internet. Am. J. Prev. Med. 2012, 42, 150-156. \\
Salloum, R.G.; Osman, A.; Maziak, W.; Thrasher, J.F. How popular is \\
waterpipe tobacco smoking? Findings from internet search queries. \\
Tob. Control 2014. \\
Carroll, M.V.; Shensa, A.; Primack, B.A. A comparison of cigarette- and \\
hookah-related videos on YouTube. Tob. Control 2013, 22, 319-323. \\
Brockman, L.N.; Pumper, M.A.; Christakis, D.A.; Moreno, M.A. Hookah's \\
new popularity among US college students: A pilot study of the \\
characteristics of hookah smokers and their facebook displays. BMJ Open \\
2012, 2, doi:10.1136/bmjopen-2012-001709.
\end{tabular}

\section{Conflicts of Interest}

The authors declare no conflict of interest.

\section{References}

1. WHO Study Group on Tobacco Product Regulation. Advisory Note: Waterpipe Tobacco Smoking: Health Effects, Research Needs and Recommended Actions by Regulators; World Health Organization: Geneva, Switzerland, 2005.

2. Chaouachi, K. Hookah (Shisha, Narghile) smoking and environmental tobacco smoke. A critical review of the relevant literature and the public health consequences. Int. J. Environ. Res. Public Health 2009, 6, 798-843.

3. Kiter, G.; Ucan, E.; Ceylan, E.; Kilinc, O. Water-pipe smoking and pulmonary functions. Resp. Med. 2000, 94, 891-894.

4. Lipkus, I.M.; Eissenberg, T.; Schwartz-Bloom, R.D.; Prokhorov, A.V.; Levy, J. Affecting perceptions of harm and addiction among college waterpipe tobacco smokers. Nicotine Tob. Res. 2011, 13, 599-610.

5. Rastam, S.; Eissenberg, T.; Ibrahim, I.; Ward, K.D.; Khalil, R.; Maziak, W. Comparative analysis of waterpipe and cigarette suppression of abstinence and craving symptoms. Addict. Behav. 2011, 36, 555-559.

6. Primack, B.A.; Longacre, M.R.; Beach, M.L.; Adachi-Mejia, A.M.; Titus, L.J.; Dalton, M.A. Association of established smoking among adolescents with timing of exposure to smoking depicted in movies. J. Natl. Cancer Inst. 2012, 104, 549-555.

7. Alzoubi, K.H.; Khabour, O.F.; Azab, M.; Shqair, D.M.; Shihadeh, A.; Primack, B.; Eissenberg, T. $\mathrm{CO}$ exposure and puff topography are associated with Lebanese waterpipe dependence scale score. Nicotine Tob. Res. 2013, 15, 1782-1786.

8. Maziak, W. Chapter 90-Waterpipe smoking. In Principles of Addiction; Miller, P.M., Ed.; Academic Press: San Diego, CA, USA, 2013; pp. 891-900. 
9. Maziak, W.; Ward, K.D.; Eissenberg, T. Factors related to frequency of narghile (waterpipe) use: The first insights on tobacco dependence in narghile users. Drug Alcohol Depend. 2004, 76, 101-106.

10. Radwan, G.; Hecht, S.S.; Carmella, S.G.; Loffredo, C.A. Tobacco-specific nitrosamine exposures in smokers and nonsmokers exposed to cigarette or waterpipe tobacco smoke. Nicotine Tob. Res. 2013, 15, 130-138.

11. Sukaina Alzyoud, L.H.; El Shahawy, O.; Ghadban, R.; Kheirallah, K.; Khalid, A. Alhawamdeh and Yan Jin-Patterns of waterpipe use among Arab immigrants in the USA: A pilot study. Br. J. Med. Med. Res. 2014, 4, doi:10.9734/BJMMR/2014/6220.

12. Primack, B.A.; Shensa, A.; Kim, K.H.; Carroll, M.V.; Hoban, M.T.; Leino, E.V.; Eissenberg, T.; Dachille, K.H.; Fine, M.J. Waterpipe smoking among U.S. university students. Nicotine Tob. Res. 2013, 15, 29-35.

13. Barnett, T.E.; Forrest, J.R.; Porter, L.; Curbow, B.A. A multiyear assessment of hookah use prevalence among Florida high school students. Nicotine Tob. Res. 2014, 16, 373-377.

14. Barnett, T.; Smith, T.; He, Y.; Soule, E.; Curbow, B.; Tomar, S.; McCarty, C. Evidence of emerging hookah use among university students: A cross-sectional comparison between hookah and cigarette use. BMC Public Health 2013, 13, doi:10.1186/1471-2458-13-302.

15. Noonan, D.; Patrick, M.E. Factors associated with perceptions of hookah addictiveness and harmfulness among young adults. Subst. Abuse 2013, 34, 83-85.

16. Carroll, T.; Poder, N.; Perusco, A. Is concern about waterpipe tobacco smoking warranted? Aust. N. Z. J. Public Health 2008, 32, 181-182.

17. Sidani, J.E.; Shensa, A.; Primack, B.A. Substance and hookah use and living arrangement among fraternity and sorority members at US colleges and universities. J. Commun. Health 2013, 38, 238-245.

18. Primack, B.A.; Hopkins, M.; Hallett, C.; Carroll, M.V.; Zeller, M.; Dachille, K.; Kim, K.H.; Fine, M.J.; Donohue, J.M.U.S. health policy related to hookah tobacco smoking. Am. J. Public Health 2012, 102, e47-e51.

19. Akl, E.A.; Gunukula, S.K.; Aleem, S.; Obeid, R.; Jaoude, P.A.; Honeine, R.; Irani, J. The prevalence of waterpipe tobacco smoking among the general and specific populations: A systematic review. BMC Public Health 2011, 11, doi:10.1186/1471-2458-11-244.

20. Abughosh, S.; Wu, I.H.; Peters, R.J.; Essien, E.J.; Crutchley, R. Predictors of persistent waterpipe smoking among university students in the United States. Epidemiology 2011, 1, doi:10.4172/ 2161-1165.1000102.

21. Brockman, L.N.; Pumper, M.A.; Christakis, D.A.; Moreno, M.A. Hookah's new popularity among US college students: A pilot study of the characteristics of hookah smokers and their Facebook displays. BMJ Open 2012, 2, doi:10.1136/bmjopen-2012-001709.

22. Fielder, R.L.; Carey, K.B.; Carey, M.P. Predictors of initiation of hookah tobacco smoking: A one-year prospective study of first-year college women. Psychol. Addict. Behav. 2012, 26, 963-968.

23. Noonan, D.; Kulbok, P.; Yan, G. Intention to smoke tobacco using a waterpipe among students in a southeastern U.S. College. Public Health Nurs. 2011, 28, 494-502.

24. Primack, B.A.; Kim, K.H.; Shensa, A.; Sidani, J.E.; Barnett, T.E.; Switzer, G.E. Tobacco, marijuana, and alcohol use in university students: A cluster analysis. J. Am. Coll Health 2012, 60, 374-386. 
25. Rice, V.H.; Weglicki, L.S.; Templin, T.; Hammad, A.; Jamil, H.; Kulwicki, A. Predictors of Arab American adolescent tobacco use. Merrill Palmer Q. 2006, 52, 327-342.

26. Shafey, O.E.D. Tobacco use: Global perspective, Arab world, and Arab Americans. ACCESS Health 2010, 1, 37-43.

27. Amrock, S.M.; Gordon, T.; Zelikoff, J.T.; Weitzman, M. Hookah use among adolescents in the United States: Results of a national survey. Nicotine Tob. Res. 2014, 16, 231-237.

28. Salloum, R.G.; Goma, F.; Chelwa, G.; Cheng, X.; Zulu, R.; Kaai, S.C.; Quah, A.C.K.; Thrasher, J.F.; Fong, G.T. Cigarette price and other factors associated with brand choice and brand loyalty in Zambia: Findings from the ITC Zambia Survey. Tob. Control 2015, 1, doi:10.1136/ tobaccocontrol-2014-051878.

29. Rice, V.H.; Weglicki, L.S.; Templin, T.; Jamil, H.; Hammad, A. Intervention effects on tobacco use in Arab and non-Arab American adolescents. Addict. Behav. 2010, 35, 46-48.

30. Jamil, H.; Templin, T.; Fakhouri, M.; Rice, V.H.; Khouri, R.; Fakhouri, H. Comparison of personal characteristics, tobacco use, and health states in Chaldean, Arab American, and non-Middle Eastern White adults. J. Immigr. Minor. Health 2009, 11, 310-317.

31. Fielder, R.L.; Carey, K.B.; Carey, M.P. Hookah, cigarette, and marijuana use: A prospective study of smoking behaviors among first-year college women. Addict. Behav. 2013, 38, 2729-2735.

32. Primack, B.A.; Fertman, C.I.; Rice, K.R.; Adachi-Mejia, A.M.; Fine, M.J. Waterpipe and cigarette smoking among college athletes in the United States. J. Adolesc. Health 2010, 46, 45-51.

33. Backinger, C.L.; Fagan, P.; O’Connell, M.E.; Grana, R.; Lawrence, D.; Bishop, J.A.; Gibson, J.T. Use of other tobacco products among U.S. adult cigarette smokers: Prevalence, trends and correlates. Addict. Behav. 2008, 33, 472-489.

34. Primack, B.; Sidani, J.; Shadel, W.; Eissenberg, T. Prevalence of and associations with waterpipe tobacco smoking among U.S. university students. Ann. Behav. Med. 2008, 36, 81-86.

35. Noonan, D.; Kulbok, P.A. Beliefs and norms associated with smoking tobacco using a waterpipe among college students. J. Addict. Nurs. 2012, 23, 123-128.

36. Nuzzo, E.; Shensa, A.; Kim, K.H.; Fine, M.J.; Barnett, T.E.; Cook, R.; Primack, B.A. Associations between hookah tobacco smoking knowledge and hookah smoking behavior among US college students. Health Edu. Res. 2013, 28, 92-100.

37. Primack, B.A.; Walsh, M.; Bryce, C.; Eissenberg, T. Water-pipe tobacco smoking among middle and high school students in Arizona. Pediatrics 2009, 123, e282-e288.

38. Sterling, K.L.; Mermelstein, R. Examining hookah smoking among a cohort of adolescent ever smokers. Nicotine Tob. Res. 2011, 13, 1202-1209.

39. Zhang, B.; Haji, F.; Kaufman, P.; Muir, S.; Ferrence, R. "Enter at your own risk": A multimethod study of air quality and biological measures in Canadian waterpipe cafes. Tob. Control 2013, 24, $175-181$.

40. Biener, L.; Nyman, A.L.; Stepanov, I.; Hatsukami, D. Public education about the relative harm of tobacco products: An intervention for tobacco control professionals. Tob. Control 2013, 23, 385-388.

41. Nakkash, R.; Khalil, J. Health warning labelling practices on narghile (Shisha, hookah) waterpipe tobacco products and related accessories. Tob. Control 2010, 19, 235-239. 
42. Kandela, P. Nargile smoking keeps Arabs in Wonderland. Lancet 2000, 356, doi:10.1016/ S0140-6736(05)72871-3.

43. Asfar, T.; Ward, K.D.; Eissenberg, T.; Maziak, W. Comparison of patterns of use, beliefs, and attitudes related to waterpipe between beginning and established smokers. BMC Public Health 2005, 5, doi:10.1186/1471-2458-5-19.

44. Misek, R.; Patte, C. Carbon monoxide toxicity after lighting coals at a hookah bar. J. Med. Toxicol. 2014, 10, 295-298.

45. Jacob, P., 3rd; Abu Raddaha, A.H.; Dempsey, D.; Havel, C.; Peng, M.; Yu, L.; Benowitz, N.L. Nicotine, carbon monoxide, and carcinogen exposure after a single use of a water pipe. Cancer Epidemiol. Biomark. Prev. 2011, 20, 2345-2353.

46. Shihadeh, A.L.; Eissenberg, T.E. Significance of smoking machine toxicant yields to blood-level exposure in water pipe tobacco smokers. Cancer Epidemiol. Biomark. Prev. 2011, 20, 2457-2460.

47. Singh, S.; Soumya, M.; Saini, A.; Mittal, V.; Singh, U.V.; Singh, V. Breath carbon monoxide levels in different forms of smoking. Indian J. Chest Dis. Allied Sci. 2011, 53, 25-28.

48. Chaouachi, K. Prevention and sporadic carbon monoxide poisoning related to shisha (hookah, narghile) tobacco smoking. J. Emerg. Med. 2012, 42, 65-66.

49. Islami, F.; Nasseri-Moghaddam, S.; Pourshams, A.; Poustchi, H.; Semnani, S.; Kamangar, F.; Etemadi, A.; Merat, S.; Khoshnia, M.; Dawsey, S.M.; et al. Determinants of gastroesophageal reflux disease, including hookah smoking and opium use- a cross-sectional analysis of 50,000 individuals. PLoS ONE 2014, 9, doi:10.1371/journal.pone.0089256.

50. Kassem, N.O.; Daffa, R.M.; Liles, S.; Jackson, S.R.; Kassem, N.O.; Younis, M.A.; Mehta, S.; Chen, M.; Jacob, P., 3rd; Carmella, S.G.; et al. Children's exposure to secondhand and thirdhand smoke carcinogens and toxicants in homes of hookah smokers. Nicotine Tob. Res. 2014, 16, 961-975.

51. Sadjadi, A.; Derakhshan, M.H.; Yazdanbod, A.; Boreiri, M.; Parsaeian, M.; Babaei, M.; Alimohammadian, M.; Samadi, F.; Etemadi, A.; Pourfarzi, F.; et al. Neglected role of hookah and opium in gastric carcinogenesis: A cohort study on risk factors and attributable fractions. Int. J. Cancer 2014, 134, 181-188.

52. Elias, W.; Assy, N.; Elias, I.; Toledo, T.; Yassin, M.; Bowirrat, A. The detrimental danger of Water-Pipe (Hookah) transcends the hazardous consequences of general health to the driving behavior. J. Transl. Med. 2012, 10, doi:10.1186/1479-5876-10-126.

53. Ward, K.D. The waterpipe: An emerging global epidemic in need of action. Tob. Control 2015, 24, i1-i2.

54. Sibai, A.M.; Tohme, R.A.; Almedawar, M.M.; Itani, T.; Yassine, S.I.; Nohra, E.A.; Isma'eel, H.A. Lifetime cumulative exposure to waterpipe smoking is associated with coronary artery disease. Atherosclerosis 2014, 234, 454-460.

55. Jawad, M.; McEwen, A.; McNeill, A.; Shahab, L. To what extent should waterpipe tobacco smoking become a public health priority? Addiction 2013, 108, 1873-1884.

56. Primack, B.A.; Rice, K.R.; Shensa, A.; Carroll, M.V.; DePenna, E.J.; Nakkash, R.; Barnett, T.E.U.S. hookah tobacco smoking establishments advertised on the internet. Am. J. Prev. Med. 2012, 42, $150-156$.

57. Pascale, S.; Zeina, A.B.; Mirna, W. Saliva cotinine and exhaled carbon monoxide in real life waterpipe smokers: A post hoc analysis. Tob. Use Insights 2009, 2009, 1-10. 
58. Barnett, T.E.; Curbow, B.A.; Soule, E.K., Jr.; Tomar, S.L.; Thombs, D.L. Carbon monoxide levels among patrons of hookah cafes. Am. J. Prev. Med. 2011, 40, 324-328.

59. De Leon, E.; Smith, K.C.; Cohen, J.E. Dependence measures for non-cigarette tobacco products within the context of the global epidemic: A systematic review. Tob. Control 2013, 23, 197-203.

60. Khabour, O.F.; Alzoubi, K.H.; Eissenberg, T.; Mehrotra, P.; Azab, M.; Carroll, M.V.; Afifi, R.A.; Primack, B.A. Waterpipe tobacco and cigarette smoking among university students in Jordan. Int. J. Tuberc Lung Dis. 2012, 16, 986-992.

61. Maziak, W.; Eissenberg, T.; Ward, K.D. Patterns of waterpipe use and dependence: Implications for intervention development. Pharmacol. Biochem. Behav. 2005, 80, 173-179.

62. Maziak, W.; Hammal, F.; Rastam, S.; Asfar, T.; Eissenberg, T.; Bachir, M.E.; Fouad, M.F.; Ward, K.D. Characteristics of cigarette smoking and quitting among university students in Syria. Prev. Med. 2004, 39, 330-336.

63. Maziak, W.; Ward, K.D.; Afifi Soweid, R.A.; Eissenberg, T. Standardizing questionnaire items for the assessment of waterpipe tobacco use in epidemiological studies. Public Health 2005, 119, 400-404.

64. Ali, A.Y.; Safwat, T.; Onyemelukwe, G.; Otaibi, M.A.; Amir, A.A.; Nawas, Y.N.; Aouina, H.; Afif, M.H.; Bolliger, C.T. Smoking prevention and cessation in the Africa and Middle East region: A consensus draft guideline for healthcare providers-Executive summary. Respiration 2012, 83, 423-432.

65. Haddad, L.; El-Shahawy, O.; Shishani, K.; Madanat, H.; Alzyoud, S. Cigarette use attitudes and effects of acculturation among Arab immigrants in USA: A preliminary study. Health 2012, 4, 785-793.

66. Haddad, L.; Baker, A.; EL-Shahawy, O.; Al-Ali, N.; Shudayfat, T. Secondhand smoke exposure among young adults in a developing country-A Jordanian case. J. Subst. Abuse Rehabil. 2013, 2013, 45-53.

67. Chaouachi, K. Public health intervention for narghile (hookah, shisha) use requires a radical critique of the related "standardised" smoking machine. J. Public Health 2009, 18, 69-73.

68. Akl, E.A.; Jawad, M.; Lam, W.Y.; Co, C.N.; Obeid, R.; Irani, J. Motives, beliefs and attitudes towards waterpipe tobacco smoking: A systematic review. Harm. Reduct. J. 2013, 10, 12. doi:10.1186/1477-7517-10-12.

69. Hoek, J.; Maubach, N.; Stevenson, R.; Gendall, P.; Edwards, R. Social smokers' management of conflicted identities. Tob. Control 2013, 22, 261-265.

70. Moran, S.; Wechsler, H.; Rigotti, N.A. Social smoking among US college students. Pediatrics 2004, 114, 1028-1034.

71. Sharma, E.; Beck, K.H.; Clark, P.I. Social context of smoking hookah among college students: Scale development and validation. J. Am. Coll. Health 2013, 61, 204-211.

72. Paul, C.L.; Ross, S.; Bryant, J.; Hill, W.; Bonevski, B.; Keevy, N. The social context of smoking: A qualitative study comparing smokers of high versus low socioeconomic position. BMC Public Health 2010, 10, doi:10.1186/1471-2458-10-211.

73. Burke, N.J.; Joseph, G.; Pasick, R.J.; Barker, J.C. Theorizing social context: Rethinking behavioral theory. Health Educ. Behav. 2009, 36, 55S-70S. 
74. Purvis Cooper, C.; Burgoon, M.; Roter, D.L. An expectancy-value analysis of viewer interest in television prevention news stories. Health Commun. 2001, 13, 227-240.

75. Fox, S. Pew Internet: Health. Available online: http://www.pewinternet.org/Commentary/2011/ November/Pew-Internet-Health.aspx (accessed on 29 March 2014).

76. Eng, T.R.; Maxfield, A.; Patrick, K.; Deering, M.J.; Ratzan, S.C.; Gustafson, D.H. Access to health information and support. JAMA 1998, 280, 1371-1375.

77. Jin, Y.; Liu, B.F. The blog-mediated crisis communication model: Recommendations for responding to influential external blogs. J. Public Relat. Res. 2010, 22, 429-455.

78. Myslin, M.; Zhu, S.H.; Chapman, W.; Conway, M. Using twitter to examine smoking behavior and perceptions of emerging tobacco products. J. Med. Internet. Res. 2013, 15, doi:10.2196/ jmir.2534.

79. Salloum, R.G.; Osman, A.; Maziak, W.; Thrasher, J.F. How popular is waterpipe tobacco smoking? Findings from internet search queries. Tob. Control 2014, 6, doi:10.1136/ tobaccocontrol-2014-051675.

80. De Jesus, $M$. The impact of mass media health communication on health decision-making and medical advice-seeking behavior of U.S. hispanic population. Health Commun. 2013, 28, 525-529.

81. Gray, N.J.; Klein, J.D.; Noyce, P.R.; Sesselberg, T.S.; Cantrill, J.A. Health information-seeking behaviour in adolescence: The place of the internet. Soc. Sci. Med. 2005, 60, 1467-1478.

82. Meganck, S.; Quarforth, S.; Messner, M.; Sherman, S. From web to mobile: A meta-analysis of trends in digital health communication research, 2001-2010. In Proceedings of the 15th International Public Relations Research Conference, Miami, FL, USA, 8-10 March 2011.

83. Liu, B.F.; Jin, Y.; Briones, R.; Kuch, B. Managing turbulence in the blogosphere: Evaluating the blog-mediated crisis communication model with the American Red Cross. J. Pub. Relat. Res. 2012, 24, 353-370.

84. McCarthy, M. FDA moves to regulate e-cigarettes and pipe and hookah tobacco. BMJ 2014, 348, doi:10.1136/bmj.g2952.

85. Morris, D.S.; Fiala, S.C.; Pawlak, R. Opportunities for policy interventions to reduce youth hookah smoking in the United States. Prev. Chron. Dis. 2012, 9, doi:10.5888/pcd9.120082.

86. Jawad, M.; McEwen, A.; McNeill, A.; Shahab, L. The importance of addressing waterpipe tobacco smoking: Research and policy responses. Addiction 2013, 108, 1887-1888.

87. Jawad, M.; el Kadi, L.; Mugharbil, S.; Nakkash, R. Waterpipe tobacco smoking legislation and policy enactment: A global analysis. Tob. Control 2014, 12, doi:10.1136/tobaccocontrol-2014-051911.

88. Griffiths, M.A.; Harmon, T.R.; Gilly, M.C. Hubble bubble trouble: The need for education about and regulation of hookah smoking. J. Pub. Policy Mark 2011, 30, 119-132.

89. Gonzalez, M.; Green, L.W.; Glantz, S.A. Through tobacco industry eyes: Civil society and the FCTC process from Philip morris and British American tobacco's perspectives. Tob. Control 2011, 21, doi:10.1136/tc.2010.041657.

90. Maher, J.E.; Morris, D.S.; Girard, K.E.; Pizacani, B.A. Consequences of clean indoor air exemptions in Oregon: The hookah story. Tob. Control 2014, 23, 195-196. 
91. US Department of Health and Human Services. Preventing Tobacco Use among Youth and Young Adults: A Report of the Surgeon General; US Department of Health and Human Services, Centers for Disease Control and Prevention, National Center for Chronic Disease Prevention and Health Promotion, Office on Smoking and Health: Atlanta, GA, USA, 2012; p. 2.

92. Tobacco Control Legal Consortium. Regulatory Options for Hookahs and Water Pipes. Available online: http://www.publichealthlawcenter.org (accessed on 2 April 2015).

93. Family Smoking Prevention and Tobacco Control and Federal Retirement Reform. 2009. pp. 111-131. Available online: www.gpo.gov/fdsys/pkg/PLAW-111publ31/pdf/PLAW111publ31.pdf (accessed on 2 April 2015).

94. Alcohol and Tobacco Tax and Trade Bureau, U.S. Department of Treasury. Tax and Fee Rates. Available online: http://www.ttb.gov/tax_audit/atftaxes.shtml\#Tobacco (accessed on 2 April 2015).

95. Carroll, M.V.; Shensa, A.; Primack, B.A. A comparison of cigarette- and hookah-related videos on YouTube. Tob. Control 2013, 22, 319-323.

96. Hu, X.; Primack, B.A.; Barnett, T.E.; Cook, R.L. College students and use of K2: An emerging drug of abuse in young persons. Subst. Abuse Treat. Prev. Policy 2011, 6, doi:10.1186/1747-597X-6-16.

(C) 2015 by the authors; licensee MDPI, Basel, Switzerland. This article is an open access article distributed under the terms and conditions of the Creative Commons Attribution license (http://creativecommons.org/licenses/by/4.0/). 